\title{
"Ceria"
}

Jurnal Program Studi Pendidikan Anak Usia Dini

ISSN 2301-9905

Volume 13, No 2 Januari 2021

Fakultas Keguruan dan Ilmu Pendidikan - Universitas Muhammadiyah Tangerang

\section{Analisi Kompensi Pedagogik Guru Taman Kanak-Kanak Dalama Pembelajaran Jarak Jauh Selama Masa Covid-19}

${ }^{1}$ Titi Rachmi, ${ }^{2}$ Aqidatul Nabilah,

1,2 Program Studi Pendidikan Guru Pendidikan Anak Usia Dini ; Fakultas Keguruan Dan

Ilmu Pendidikan; Universitas Muhammadiyah Tangerang

e-mail:1Titirachmi@gmail.com, ${ }^{2}$ AqidatulNabilah@gmail.com,

\begin{abstract}
Abstrak
Penelitian ini dilakukan dengan adanya permasalahan Kompetensi Pedagogik Guru Taman Kanak-Kanak Dalam Pembelajaran Jarak Jauh Selama Masa Covid-19 di Kota dan Kabupaten Tangerang. Tujuan dari penelitian ini adalah untuk mengetahui bagaimana guru memberikan pengajaran dalam pembelajaran jarak jauh selama covid-19 serta mengetahui kompetensi guru yang di gunakan, sehingga masalah pembelajaran jarak jauh selama covid19 dapat membuktikan dan menjelaskan statergi kegiatannya berjalan sesuai dengan rancangan yang disusun oleh setiap sekolah. Teknik analisis yang digunakan dalam penelitian ini adalah analisis deskriptif kualitatif dengan proses transformasi data penelitian dalam bentuk tabulasi. Penelitian ini di lakukan pada sepuluh sekolah di Kota dan Kabupaten wilayah Tangerang Banten. Pengumpulan data dilakukan dengan pengamatan langsung di lapangan dan dengan wawancara. Hasil dari penelitian ini menujukkan bahwa proses pembelajaran jarak jauh selama covid-19 telah dilaksanakan dengan menerapkan kompetensi pedagogik yang dimiliki oleh seorang guru taman kanakkanak. sedangkan untuk kompetensi pedagogik guru taman kanak-kanak baik secara pelaksanaanya selama daring sudah baik, namun harus tetap adanya bimbingan yang diambil melalui pengetahuan oleh para guru di Kota dan Kabupaten Tangerang Banten.
\end{abstract}

Kata kunci : Kompetensi Pedagogik, Pembelajaran Jarak Jauh 


\section{Pengantar}

Perkembangan anak memiliki beberapa aspek. Hal ini termasuk dalam Peraturan Menteri Pendidikan dan Kebudayaan Republik Indonesia nomor 137 tahun 2014 tentang Standar Nasional Pendidikan Anak Usia Dini menjelaskan bahwa terdapat enam aspek perkembangan anak yakni, nilai agama moral, fisik motorik (motorik kasar dan motorik halus), kognitif, bahasa, sosial emosional dan seni. Salah satu aspek perkembangan yang distimulasi adalah perkembangan kognitif (Nurzakinah \& Sri, 2019). Perkembangan kognitif mencakup kemampuan berfikir anak dan memacahkan masalah.

Pendidikan untuk anak usia dini di Indonesia memiliki pondasi yang kuat dalam menyelengarakan pendidikan sesuai dengan sistem undang- undang pendidikan indonesia pada setiap sekolah anak usia dini . karena pendidikan anak usia dini sangat mempengaruhi aspek perkembangan anak berdasarkan usia anak dari berusia 0 sampai usia 6 tahun. Hal ini membantu anak dalam mengeksplorasikan aspek perkembangan salah satunya aspek perkembangan kognitif yang mudah distimulasi kan oleh anak. Aspek perkembangan yang baik akan memiliki kesiapan dalam melanjutkan pendidikan anak selanjutnya. Sebagaimana yang di kutip oleh Sudargo, dkk (2018:47) menjelaskan bahwa "kognitif merupakan pengamatan yang melibatkan bagaimana individu memperoleh, menyimpan, mendapatkan kembali dengan pengetahuan".

Berdasarkan observasi penelitian yang ditemukan saat ini pada masa covid-19 adalah kurangnya proses pembelajaran efektif dan efesien bagi siswa maupun guru dilakukan tidak dalam bentuk tatap muka langsung antar pengajar dan pembelajar melainkan komunikasi berlangsung dua arah yang dijembatani dengan media seperti komputer, telephone, internet, wifi, video dan sebagainnya. Kurangnya pengetahuan oleh guru dan wali murid jika tidak tau menggunakan aplikasi online untuk proses pembelajaran anak. Kurangnya akses internet dan sinyal internet terkadang memburuk, hal ini mempengaruh untuk kelancaran proses pembelajarannya. Kompetensi pedagogik guru dalam menguasai media online tidak semuanya guru menguasai. Hal ini akan sulit untuk mengajarkan tema / materi pada siswa saat proses pembelajaran jarak jauh. 


\section{Metode}

Metode yang digunakan ini adalah metode kualitatif dengan jenis metode studi kasus. Penelitian kualitatif di definisikan sebagai metodologi yang menyediakan alat-alat dalam memahami arti secara mendalam yang berkaitan dengan fenomena yang kompleks dan prosesnya dalam praktik kehidupan sosial. (Helaludin \& Wijaya, 2019). Dalam penelitian kualitatif, Studi Kasus adalah penelitian kualitatif yang mencakup pada kasus tertentu secara mendalam sehingga dapat mengidentifikasi hubungan sosial, proses dan kategori yang secara bersamaan dapat dikenali, khas, dan unik. Prihatsanti, Suryanto, \& Hendriani (2018) mengungkapkan bahwa tujuan dari studi kasus itu sendiri adalah untuk memberikan analisis tentang konsteks dan proses yang berkaitan dengan isu teoritis yang sedang dipelajari. Selain itu Hartley (2004) berpendapat bahwa studi kasus tidak dapat dipisahkan dari konteksnya, tetapi menjadi menarik ketika tujuanya memahami perilaku yang dipengaruhi oleh kontens tertentu.

\section{Hasil dan Pembahasan}

Penelitian ini dilakukan di TK yang berada di Kota dan Kabupaten Tangerang, Penelitian dilakukan peneliti dengan melakukan observasi awal pada bulan Febuari 2020 tepatnya pada saat covid-19 ada di Indonesia, peneliti hadir sebagai pengamat berjalannya proses belajar mengajar dan tidak ikut campur langsung dalam proses belajar mengajar yang sedang berlangsung. Selama observasi awal, peneliti mulai menemukan adanya perbedaan pengajaran dalam proses pembelajaran secara normal pada umumnya. Pembelajaran pada masa covid-19 ini guru dan peserta didik tidak melakukan kegiatan pembelajaran yang efektif di dalam ruangan sekolah ataupun di lingkungan sekolah dengan tidak adanya tatap muka antara guru dan peserta didik. Proses pembelajaran pada masa pademik covid-19 ini guru dan peserta didik melakukan kegiatan belajar mengajar menggunakan bantuan teknologi yang terhubung dengan jaringan internet. Pada kegiatan 
pembelajaran jarak jauh terlihat kompotensi pedagogik guru taman kanak-kanak memiliki kesulitan dalam pengajaran saat proses pembelajaran belangsung kepada peserta didik.

\section{Guru yang berpengalaman dan memiliki wawasan ilmu pendidikan sangat berpengaruh dengan kompetensi pedagogik guru taman kanak-kanak.}

Seperti yang kita ketahui bahwa kompetensi pedagogik guru taman kanak-kanak yang sebenarnya adalah kompetensi yang sesuai dengan Peraturan Menteri Pendidikan Dan Kebudayaan Republik Indonesia No.137 tahun 2014 yang berisi tentang Kompetensi Tenaga Kependidikan. jadi sebagai pendidik harus memiliki kompetensi guru paud berdasarkan standar nasional.

Berikut temuan-temuan yang didapatkan dari hasil wawancara tentang guru yang berpengalaman dan memiliki wawasan ilmu pendidikan sangat berpengaruh dengan kompetensi pedagogik guru taman kanak-kanak: hal ini di ungkapkan dengan ada nya acuan 10 kompetensi guru paud, guru TK yang persepsi bahwa guru yang berpengalaman sangat berpengaruh dengan kompetensi pedagogik guru TK. Menurut dari lima guru TK dari sepuluh guru TK di Kota dan Kab Tangerang menyatakan bahwa guru dapat membuat program pembelajaran yang menyenangkan yang pernah dibuat oleh guru sebelumnya (CW2.6), membuat program pembiasaan untuk anak yang mendidik (CW2. 9), membuat pembelajaran dengan aspek perkembangan anak / kegiatan sentra (CW2.18).

\section{Proses pembelajaran jarak jauh selama covid-19.}

Seperti yang kita ketahui bahwa proses pembelajaran jarak jauh selama covid-19 adalah cara belajar mandiri, materi pembelajaran disampaikan melalui media, dan tidak ada kontrak langsung antara pengajar dengan pembelajar. dalam proses pembelajaran jarak jauh selama covid-19 adanya perbeda dengan proses pembelajaran secara langsung dimana orang tua dilibatkan dalam pembelajaran dan penilaiannya. 
Jurnal Program Studi Pendidikan Anak Usia Dini

"Ceria"

Berikut temuan-temuan yang didapatkan dari hasil wawancara tentang proses pembelajaran jarak jauh covid-19. Menurut sepuluh narasumber yang merupakan guru TK di Kota dan Kabupaten Tangerang mengenai proses pembelajaran jarak jauh selama covid-19 yaitu: mengatakan bahwa dalam proses pembelajaran jarak jauh penyusunan program rancangan tetap dibuat oleh staff guru dan kepala sekolah, hal ini dapat dilihat berdasarkan hasil kesimpulan wawancara guru yang mengatakan staff guru dan kepala sekolah yang menyusun rancangan sekolah tersebut (CW2. 2), mengatakan bahwa kegiatan PJJ tetap memiliki langkah-langkah pembelajaran namun sedikit perberbeda dengan langkah-langkah pembelajaran terhadap tatap muka langsung ,dapat disimpulkan hasil wawancara guru tetap menyiapkan rancangan pembelajaran, adanya persiapan bahan ajar dan mengurangi kegiatan pembelajaran dikarenakan jangka waktu yang sangat pendek (CW2. 7).

Selanjutnya mengatakan bahwa dalam proses pembelajaran guru tetap tidak memberikan pekerjaan rumah /PR saat selesai proses kegiatan pembelajaran (CW2. 8), dan (CW2.15) mengatakan saat proses pembelajaaran jarak jauh respon anak-anak memiliki respon yang berbeda-beda, namun dapat disimpulkan bahwa respon anak sangat tidak nyaman karena tidak bisa berinteraksi secara langsung kepada gurunya.

\section{Masalah-masalah yang dihadapi oleh guru taman kanak-kanak saat proses belajar} mengajar pada kegiatan pembelajaran jarak jauh.

Seperti yang kita ketahui bahwa masalah- masalah yang dihadapi oleh guru taman kanak-kanak saat proses belajar mengajar pada kegiatan pembelajaran jarak jauh. Berdasarkan hasil penemuan yang di dapatkan oleh peneliti melalui beberapa pertanyaan untuk guru yang menghadapi pengajaran kegiatan PJJ. hal ini dapat di ungkapan dari jawaban soal wawacara no 13,14,16,17 dan 20 tentang masalah yang di hadapi oleh guru paud dalam kegiatan PJJ. Yaitu: hasil wawancara no 13 menyatakan pada saat proses pembelajaran jarak jauh terdapat kesulitan yang dialami oleh guru, dari hasil wawancara guru bahwa guru merasa kesulitan yaitu : kurangnya jaringan internet 
yang tidak memadai, keterbatasan waktu dalam proses pengajaran, kurangnya interaksi dengan anak sehingga tidak dapat melihat langsung proses pekermbangan aspek pada anak (CW2. 13). hasil wawancara no 14 menyatakan bahwa kegiatan PJJ sangat tidak efektif, dilihat pada hasil lampiran wawancara guru jika anak merasa mudah belajar dengan adanya kegiatan pembelajaran secara langsung serta dapat berinteraksi lansung oleh guru dan teman sebayanya (CW2. 14).

Pada hasil wawancara no 16 menyatakan bahwa guru memiliki rasa ketidaknyaman karena tidak dapet berinteraksi lansung dengan anak dan tidak sepenuhnya menilai kegiatan yang sesuai dengan perkembangan aspek anak, hal ini dapat dilihat berdasarkan lampiran hasil wawacara dengan guru (CW2. 16). wawancara no 17 menyatakan jika yang di rasakan oleh orang tua dengan adanya kegiatan PJJ yaitu ada rasa nyaman dan tidak nyaman, hasil ini dapat dilihat berdasarkan kesimpulan lampiran wawancara guru bahwa ketidaknyaman orang tua yaitu, ketika anak sulit bekerjasama untuk menyelesaikan pembelajaran dan kenyamannya telihat ketika orang tidak khawatir akan kesehatan pada masa pademik untuk terhidar dari kerumunan di sekolah (CW2. 17). pada no 20 tentang kompetensi apa yang teramati oleh anak, hal ini dapat dilihat berdasarkan hasil wawancara bahwa kesimpulannya kompetensi yang teramati yaitu: anak lebih bertanggung jawab dalam mengejakan, mandiri dan dapat terawasi oleh orang tua (CW2. 20). hasil wawancara diatas dapat dilihat berdasarkan lampiran hasil dokumentasi penelitian (CD4.1).

\section{Kesimpulan}

Berdasarkan hasil penelitian yang telah dilaksanakan serta dapat tertuang dalam hasil dan pembahasan, maka dapat ditarik kesimpulan akhir dari penelitian kompetensi pedagogik guru taman kanak-kanak dalam pembelajaran jarak jauh selama masa covid-19, yaitu sebagai berikut: a). Guru yang berpengalaman dan memiliki wawasan ilmu pendidikan sangat berpengaruh dengan kompetensi pedagogik guru taman kanak-kanak dalam pembelajaran jarak jauh di masa pademik ini, guru telah menerapkan dengan adanya 
kompetensi guru yang dimiliki. Hal ini dibuktikan ketika guru dapat mencari informasi materi dan tema pembelajaran melalui media sosial / internet. Tidak hanya itu namun guru dapat mengembangkan wawasan keilmuannya melalui pengentahuan media teknologi internet dengan informasi dan komunikasi, b). Proses pembelajaran jarak jauh selama covid19 dalam kegiatatan ini guru tetap melakukan pembelajaran dengan langkah-langkah pembelajaran jarak jauh yang memang sudah di persiapkan. Hal ini dapat di buktikan saat proses pembelajaran jarak jauh di mulai. Guru melalukan persiapan bedasarkan tema/ materi pembelajaran, seperti : guru mempersiapkan rancangan pembelajaran, guru mempersiapkan bahan ajar / media mengajar, dan memberikan informasi kegiatan pembelajaran kepada peserta didik melalui orang tua di grup whatsapp, c). Masalah-masalah yang dihadapi oleh guru taman kanak-kanak saat proses belajar mengajar pada kegiatan pembelajaran jarak jauh selama masa pademik ini ada beberapa masalah yang dapat dilihat pada saat kegiatan mengajar-belajara, yaitu: adanya kendala jaringan internet seperti susah jaringan yang tidak memadai, tidak merasa nyaman dengan kegiatan pembelajaran yang tidak dapat berinteraksi langsung atau bertatap muka antara pendidik dengan peserta didik. Hal ini dapat berpengaruh dalam penilaian/assemen,dimana guru tidak sepenuhnya menilai pengembangan anak sesuai 6 aspek perkembangan anak usia dini.

\section{Daftar Pustaka}

Nurzakinah, D. S., \& Sri, W. (2019). KONSEP BILANGAN PADA ANAK KELOMPOK B DI TK AF Abstrak. PAUD Teratai, 8, 1-6.

Sugiyono. (2016). (2016). kualitatif. Bandung.

Rahayu, D. (2019). WORKSHOP PENERAPAN PENGELOLAAN PEMBELAJARAN UNTUK MENINGKATKAN KOMPETENSI PEDAGOGIK GURU TK DI GUGUS III PKG KOTA MATARAM Dwi. Journal of Chemical Information and Modeling, 53(9), 1689-1699. https://doi.org/10.1017/CBO9781107415324.004

Yaumi, D. D. (2019). Model Integrasi Teknologi Informasi dan Komunikasi dalam Pembelajaran Jarak Jauh. 1(2), 138-150.

Yerusalem, D. (2015). Desain dan Implementasi Sistem Pembelajaran Jarak Jauh Di Program Studi Sistem Komputer. Jurnal Teknologi Dan Sistem Komputer, 3(4), 481. 
Jurnal Program Studi Pendidikan Anak Usia Dini

"Ceria”

https://doi.org/10.14710/jtsiskom.3.4.2015.481-492

Setiawan, T. H., \& Rahman, A. N. (2020). Pelatihan daring teknologi pembelajaran. $01(01), 37-47$.

Sadikin, A., \& Hamidah, A. (2019). Pembelajaran Fiqh Mu'Āmalāt Berorientasi Literasi Finansial. TARBAWY: Indonesian Journal of Islamic Education, 6(2), 187-192. https://doi.org/10.17509/t.v6i2.20887 